April 2010

\title{
"Ethnic Cleansing” and Genocidal Intent: A Failure of Judicial Interpretation?
}

Douglas Singleterry

Follow this and additional works at: https://digitalcommons.usf.edu/gsp

\section{Recommended Citation}

Singleterry, Douglas (2010) "'Ethnic Cleansing" and Genocidal Intent: A Failure of Judicial Interpretation?," Genocide Studies and Prevention: An International Journal: Vol. 5: Iss. 1: Article 4.

Available at: https://digitalcommons.usf.edu/gsp/vol5/iss1/4

This Articles is brought to you for free and open access by the Open Access Journals at Digital Commons @ University of South Florida. It has been accepted for inclusion in Genocide Studies and Prevention: An International Journal by an authorized editor of Digital Commons @ University of South Florida. For more information, please contact digitalcommons@usf.edu. 


\title{
“Ethnic Cleansing" and Genocidal Intent: A Failure of Judicial Interpretation?
}

\author{
Douglas Singleterry \\ Dughi \& Hewit, Cranford, NJ
}

This article analyzes the similarities and distinctions between "ethnic cleansing" and genocide in the context of both Bosnia's and Croatia's genocide claims against Serbia brought before the International Court of Justice (ICJ). It examines the institutional role of the ICJ and the criticisms on how the Court handled Bosnia and Herzegovina v. Serbia and Montenegro. The legal definition and elements of genocide as contained in the UN Convention on the Prevention and Punishment of the Crime of Genocide (UNCG) are discussed, with a particular emphasis on the required intent to "destroy" a protected group. The article reviews case law from other international tribunals and argues that evidence of "ethnic cleansing" may demonstrate the intent to "destroy" a protected group and support a finding of genocide.

Key words: Bosnian genocide, ethnic cleansing, International Court of Justice, Genocide Convention, Serbia, Croatia

On 18 November 2008, the International Court of Justice (ICJ) ruled that it had jurisdiction to examine Croatia's allegation that Serbia committed genocide during the 1991-1995 Croatian War. ${ }^{1}$ The country was seeking compensation for what it described as "a form of genocide which resulted in large numbers of Croatian citizens being displaced, killed, tortured, or illegally detained as well as extensive property destruction." 2 This development carries important implications both for the adjudication of genocide and the role of the ICJ. Notably, it marks only the second time in the ICJ's sixty-five-year history that the Court has agreed to review a claim arising from the UN Convention on the Prevention and Punishment of the Crime of Genocide (UNCG). ${ }^{3}$

Just a year and half earlier, the ICJ had decided similar claims in Bosnia and Herzegovina v. Serbia and Montenegro. (The Federal Republic of Yugoslavia became known as Serbia and Montenegro after 2001 and as Serbia following Montenegro's succession in 2006.) On 26 February 2007, the ICJ found that Serbia did not commit genocide during the Bosnian War from 1992 to 1995. However, the Court did find that Serbia violated its obligations under the UNCG by failing to prevent genocide in the Bosnian community of Srebrenica in 1995. The Court further ruled that Serbia was liable for not fully cooperating with the International Criminal Tribunal for the former Yugoslavia (ICTY), including the failure to bring Ratko Mladic (Chief of Staff of the Army of the Republika Srpska) to the tribunal for trial. Furthermore, the Court held that Serbia should take steps to punish those responsible for the genocide but that it did not have to pay reparations. ${ }^{4}$ Consequently, this heralded the first time a nation-state was in any way deemed responsible for violating the UNCG.

Douglas Singleterry, “'Ethnic Cleansing' and Genocidal Intent: A Failure of Judicial Interpretation?" Genocide Studies and Prevention 5, 1 (April 2010): 39-67. (C) 2010 Genocide Studies and Prevention. doi:10.3138/gsp.5.1.39 
This landmark ruling established that a nation-state, as opposed to individuals, could be held accountable for genocide under the Convention. The opinion also innovatively confirmed that nation-states must deploy "all means reasonably available to them, so as to prevent genocide so far as possible ..." Despite the import of this holding, the decision is limited by the finding that genocide only occurred in Srebrenica and that Serbia was not an active participant. Moreover, the Court has been roundly criticized for its reliance on the corresponding work of the ICTY, the standard of proof employed, and the methodology used to examine evidence. ${ }^{6}$ These factors could influence how similar claims, such as Croatia's, are handled. They also expose the Court's institutional limitations, prompting some to question whether the ICJ is even an appropriate forum to contest genocide claims. ${ }^{7}$

These deficiencies most likely contributed to the Court's limited conclusions, despite widespread evidence of "ethnic cleansing" coupled with murder and other abuses. Further, the opinion raises questions over how evidence of "ethnic cleansing" should fit into the broader legal framework when evaluating claims of genocide. As we will see, genocide and "ethnic cleansing" are distinct concepts that share similar features. Specifically, how do the motivations behind "ethnic cleansing" elucidate contentions over the genocidal intent to "destroy" a particular group? As the Court assays Croatia's allegations, it is worth reviewing the institutional role of the ICJ, the characteristics of "ethnic cleansing" and genocide, and the issues presented by both Bosnia and Croatia.

\section{The World Court}

Situated at the Peace Palace in The Hague, the ICJ, also commonly referred to as the World Court, is the principal judicial organ of the United Nations. ${ }^{8}$ The Court seats fifteen judges, who are nominated by nations and approved by the Security Council and General Assembly for nine-year terms and who are distributed by region. ${ }^{9}$ Like its predecessor, the Permanent Court of International Justice, the ICJ has a dual mandate: to decide contentious cases and render advisory opinions. Contentious cases involve disputes between nations and the Court's judgement is considered binding. Only nations may be parties to contentious cases. ${ }^{10}$ Advisory opinions comprise legal questions submitted by other United Nations' organs, including the General Assembly. ${ }^{11}$ While technically non-binding, advisory opinions are regarded as authoritative. The ICJ may also issue provisional orders prior to a final decision to preserve the rights of a party. ${ }^{12}$

In contentious matters, the Court has jurisdiction ${ }^{13}$ in three instances: (1) by "special agreement" where parties to a dispute agree to submit their case to the court; ${ }^{14}$ (2) cases authorized by treaty establishing that future disputes emanating from the treaty will be adjudicated by the ICJ; ${ }^{15}$ and (3) cases between nations that have accepted the compulsory jurisdiction of the Court. ${ }^{16}$ Accordingly, jurisdiction is either consensual or compulsory based on prior agreement. Article 9 of the UNCG gives the ICJ jurisdiction over state disputes arising from the UNCG. The issue of jurisdiction over Bosnia's claims was complicated by questions involving state succession and the status of Serbia's membership in the UN following the dissolution of Yugoslavia. It was ultimately determined that the Court did have jurisdiction under the UNCG, which Yugoslavia ratified in $1950 .^{17}$

If a nation refuses to comply with a final Court decision, the only recourse is for the prevailing party to petition the Security Council for "assistance" in obtaining compliance. ${ }^{18}$ Various studies suggest that, despite lack of a strong enforcement mechanism, compliance with ICJ rulings is relatively favorable. A 1987 study con- 
cluded that compliance with final ICJ decisions was approximately $80 \% .{ }^{19}$ An updated analysis found a $60 \%$ compliance rate from $1987-2004 .^{20}$ The apparent decline most likely reflects a stricter standard used to measure and define "compliance."21

In an exhaustive study, Compliance with Decisions of the International Court of Justice, Constanze Schulte also concludes that overall compliance with final judgements is often realized. ${ }^{22}$ However, the author notes that compliance can be difficult to achieve when the dispute arises from a highly charged political situation. ${ }^{23}$ Further, Schulte emphasizes the lack of compliance with provisional orders. This largely results from interim measures being "almost exclusively" requested in judicial proceedings launched unilaterally by a party when the Court's jurisdiction is in question. ${ }^{24}$ These compliance factors raise concerns specific to genocide cases, particularly in the context of ongoing armed conflict rooted in long-standing civil strife.

Prior to the 1990s, the Court had little experience with issues pertaining to human rights, let alone genocide and armed conflict. The ICJ has traditionally been regarded as a consent-based arbitrator of disputes between nation-states. During the Cold War (1947-1989), most contentious suits dealt with land, maritime, or fishing boundary disputes. ${ }^{25}$ There were four that concerned self-determination in the context of decolonization, ${ }^{26}$ while several other disputes did feature human rights issues such as apartheid, ${ }^{27}$ political asylum, ${ }^{28}$ unlawful detention of diplomats, ${ }^{29}$ and prisoners of war. ${ }^{30}$ Only two cases, both arising from the Contra war in Nicaragua, involved ongoing armed conflict. ${ }^{31}$ Likewise, most of the Court's advisory opinions related to internal issues of the UN and other international bodies or nations. ${ }^{32}$ Four addressed the collective right of self-determination, ${ }^{33}$ and only two others, adjudging reservations to the genocide treaty and the right of UN human rights rapporteurs to travel, ${ }^{34}$ touched on human rights.

The period following the Cold War has been characterized, in part, by factually complex cases that encompassed highly charged political disputes, frequently in the context of human rights and armed conflict. Examples include the 1996 advisory opinion on the legality of nuclear weapons ${ }^{35}$ and the controversial 2004 advisory opinion on the construction of Israel's wall in the Occupied Territory. ${ }^{36}$ The Court has entertained disputes involving the right to consular assistance in death penalty cases. ${ }^{37}$ Additionally, Serbia sued members of NATO after the military intervention in Kosovo, ${ }^{38}$ and Congo sued the Rwandese Republic for violations of human rights and international humanitarian law. ${ }^{39}$ (In the NATO and Congo cases, the Court found it lacked jurisdiction.) In addition to Croatia's current genocide claims, the ICJ has agreed to provide an advisory opinion on the status of Kosovo's independence. ${ }^{40}$ These chapters of the Court's post-Cold War era began on 20 March 1993 when Bosnia and Herzegovina sued Yugoslavia for alleged genocide, which was docketed during the still early stages of the conflict. ${ }^{41}$

\section{"A Problem from Hell"}

The dissolution of Yugoslavia officially began in June 1991, when Croatia and Slovenia declared independence. ${ }^{42}$ Likewise, a proclamation of Bosnia and Herzegovina sovereignty in October 1991 was followed by a referendum for independence in March 1992, which was supported by the Muslim and Croatian population. The Bosnian Serbs (31\% of the population) opposed succession and announced their own independent state of Republika Srpska. ${ }^{43}$ War immediately broke out between the two entities and was divided along ethnic lines. ${ }^{44}$ Efforts by the international community to broker a cease fire were futile. ${ }^{45}$ Instances of organized massacres, rape, torture, and other serious abuses were reported. ${ }^{46} \mathrm{~A}$ study undertaken by the UN's Commis- 
sion of Experts concluded that "ethnic cleansing" was being perpetrated, defining this term as "rendering an area ethnically homogenous by using force or intimidation to remove persons of given groups from the area." 47

The first report of the Special Rapporteur, published under the auspices of the UN Commission on Human Rights, underscored the various methods used in "ethnic cleansing," including

[r]eplacement by extremists of those elected representatives who refused to cooperate with ethnic cleansing, harassment, discrimination, beatings, torture, summary executions, expulsions, forced crossing of the confrontation line, confiscation of property, dismissal from work, intimidation, destruction of mosques, use of the siege and cutting off supplies of food and other essentials to civilian population centres. The report [of the Special Rapporteur] drew on the experience of the city and region of Bihac as well as Bosanska Dubica, Celinac, Sanski Most and Sarajevo. ${ }^{48}$

The Special Rapporteur's second report documented "ethnic cleansing" in and around Bosanski Novi, Prijedor, Doboj, Kotor Varos, Trabnik, and Trnopolje. ${ }^{49}$

The Special Rapporteur subsequently reported on

[a]ccounts and testimonies which are characteristic of the information which is increasingly becoming available from refugees regarding the systemic nature of ethnic cleansing as well as the human rights and humanitarian law violations. They show the methods by which violent change in the demographic map of Bosnia and Herzegovina has been achieved, leaving 810,000 people displaced internally and 700,000 refugees in other countries ... not only Croats and Muslims are the victims of ethnic cleansing; Serbs who refuse to cooperate with this policy have also been victimized. There are reports of the arbitrary execution of such Serbs, for example in Teslic on 2 June 1992 when three Serbs were reportedly killed for refusing to cooperate with the Yugoslav national Peoples' Army (JNA) and Serbian Democratic Party militia in persecuting Muslims and Croats. ${ }^{50}$

It was further emphasized that "ethnic cleansing" was being perpetrated through the widespread use of rape:

Rape is an abuse of power and control in which the rapist seeks to humiliate, shame, degrade and terrify the victim. In all his reports, the Special Rapporteur has emphasized the variety of methods used to achieve ethnic cleansing. Rape is one of those methods, as has been stated from the outset. In this context, rape has been used not only as an attack on the individual victim, but is used to humiliate, shame, degrade and terrify the entire ethnic group. There are reliable reports of public rapes, for example, in front of a whole village, designed to terrorize the population and force ethnic groups to flee. ${ }^{51}$

Bosnia alleged that, pursuant to state policy, Serb forces encircled civilians to cut off supplies and starve the population. Additionally, Serb forces committed "cultural genocide" by destroying historical, religious, and cultural property. ${ }^{52}$ By the end of 1995, approximately 2.7 million refugees had been displaced in Bosnia and Herzegovina. ${ }^{53}$ International organizations estimate that more than 100,000 people died from the conflict between 1992 and 1995, and two-thirds were Bosnian Muslims. ${ }^{54}$

One particularly horrific incident was the massacre of Bosnian Muslims at Srebrenica in July 1995, when Serb forces overtook 370 lightly armed Dutch peacekeepers and killed almost 8,000 men and boys. The UN had declared this area a safe haven and had pledged to protect it. ${ }^{55}$ Following a Serbian motor attack on the city market in Sarajevo in August 1995, NATO forces initiated air strikes against various Serbian military targets. ${ }^{56}$ The NATO campaign resulted in negotiations that culmi- 
nated in the Dayton Accords, signed in Paris on 14 December 1995, officially ending the war. ${ }^{57}$

During the Court's early proceedings, two provisional orders were issued, both in 1993, demanding that Serbia and Montenegro "immediately ... take all measures within its power to prevent commission of the crime of genocide." 58 These interim injunctions had little influence, as evidenced by Srebrenica. Meanwhile, concurrent with Bosnia's petition to the ICJ, the UN passed a resolution in May 1993 that created the ICTY to prosecute claims of genocide, crimes against humanity, and war crimes committed in the former Yugoslavia. ${ }^{59}$ The ICTY's work is expected to conclude in $2013 .^{60}$

The two international courts had parallel, but distinct roles. The ICJ was limited to determining the state's (Serbia's) responsibility for alleged genocide. ${ }^{61}$ It did not have jurisdiction over related but separate allegations of war crimes and crimes against humanity; nor did the Court have jurisdiction over individuals. ${ }^{62}$ As noted, the ICJ only considers disputes between nation-states, and jurisdiction under the UNCG does not incorporate other humanitarian crimes. In contrast, the ICTY was charged with examining the alleged conduct of individuals, such as Serbian President Slobodan Milosevic, in committing any war crimes, crimes against humanity, and genocide. ${ }^{63}$

Prior to the Bosnia case, genocide had not been substantially defined beyond the contours of the UNCG, and no international tribunal had ever previously considered such claims under the UNCG. ${ }^{64}$ The Nuremberg Trials, while influential, commenced prior to the UNCG and dealt primarily with charges of war crimes and crimes against humanity. ${ }^{65}$ The International Criminal Tribunal for Rwanda was subsequently created in 1994, and the Rome Statute establishing the International Criminal Court (ICC) was not effectuated until 2002, following the ratification by sixty countries. ${ }^{66}$ Consequently, there was little precedential guidance available for the ICJ on how to proceed.

\section{The Meaning of a Crime}

Responding to the atrocities of the Holocaust, the UN General Assembly passed a resolution in 1946 defining genocide as "a denial of the right of existence of entire human groups, as homicide is the denial of the right to live of individual human beings." 67 Two years later the UNCG was adopted and established genocide as a crime in violation of international law. Article 2 of the convention's definition contains three primary elements: (1) prohibited acts that qualify as genocide (i.e., killing; causing serious bodily or mental harm; inflicting conditions of life calculated to physically destroy; measures imposed to prevent births; forcibly transferring children); (2) protected groups that must be targeted; and (3) the mens rea special intent to "destroy in whole or in part a national, ethnical, racial or religious group ..."68 It wasn't until the 1990s that this document became the subject of substantial judicial interpretation defining these elements, particularly that of genocidal intent.

The word "genocide," the crime of crimes, was first coined in the 1940 s by Raphael Lemkin, a polish attorney and advisor to the US War Ministry. ${ }^{69}$ Following the 1939 German invasion of Poland, Lemkin fled and eventually relocated to the United States. In 1944, Lemkin's Axis Rule in Occupied Europe was published, which contained a thorough account of German crimes committed in Europe. This book, coupled with Lemkin's tireless advocacy, played a key role in the drafting and passage of the UNCG. ${ }^{70}$ 
Lemkin's conception of genocide was broad, encompassing not just killings but also economic, political, intellectual, and cultural destruction. As outlined in Axis Rule, the Nazi genocide occurred

through a synchronized attack on different aspects of life of the captive peoples: in the political field (by destroying institutions of self-government and imposing a German pattern of administration, and through colonization by Germans); in the social field (by disrupting the social cohesion of the nation involved and killing or removing elements such as the intelligentsia ...); in the cultural field (by promoting or destroying cultural institutions and cultural activities; by substituting vocational education for education in the liberal arts, in order to prevent humanistic thinking); in the economic field (by shifting wealth to Germans and by prohibiting the exercise of trades and occupations by people who do not promote Germanism "without reservations"); in the biological field (by a policy of depopulation and by promoting procreation by Germans in the occupied countries); and in the field of physical existence (by introducing a starvation rationing system for non-Germans and by mass killings, mainly of Jews, Poles, Slovenes and Russians); in the religious field (by interfering with the activities of the Church, which in many countries provides not just spiritual but also national leadership); in the field of morality (by attempts to create an atmosphere of moral debasement through promoting pornographic publications and motion pictures, and the excessive consumption of alcohol). ${ }^{71}$

According to the sociologist Martin Shaw, "This full explanation [of genocide] is important. It shows that genocide, for the term's inventor, was a comprehensive process in which a power 'attacked' and 'destroyed' the way of life and institutions of peoples." 72 Notwithstanding, such a broad-based definition, including a category of "cultural genocide," was rejected in the final UNCG draft. ${ }^{73}$ Shaw argues that, subsequently, the meaning of genocide has lost the broad sociological understanding articulated by Lemkins. ${ }^{74}$ This tendency is exemplified by the "conceptual proliferation" of terms connoting only some functional aspect of genocide's original notion. ${ }^{75}$

Perhaps the most well known "conceptual proliferation" is the phrase "ethnic cleansing." This term entered common parlance during the wars in Bosnia and Croatia. Providing an early description, Andrew Bell-Fialkoff wrote in 1993 that this usage

defies easy definition. At one end it is virtually indistinguishable from forced emigration and population exchange while at the other it merges with deportation and genocide. At the most general level, however, ethnic cleansing can be understood as the expulsion of an "undesirable" population from a given territory due to religious or ethnic discrimination, political, strategic or ideological considerations, or a combination of these. ${ }^{76}$

In contrast, genocide has been described as "a form of one-sided mass killing in which a state or authority intends to destroy a group." 77 In other words, the term genocide is meant to convey "mass killing," whereas "ethnic cleansing" signifies the forced removal from a particular territory. The Rome Statute of the ICC recognizes the "deportation or forcible transfer of population" as a crime against humanity. ${ }^{78}$

The word "genocide" carries compelling political and legal implications; perhaps contributing to a reluctance of the world community to invoke it. Critics argue that substituting the term "genocide" with "ethnic cleansing" communicates a lower level of alarm and responsibility to act. ${ }^{79}$ The term itself is suspect: 
Genocide has been the leading cause of preventable violent death in the 20th-21st century, taking even more lives than war. The term ethnic cleansing is used as a euphemism for genocide despite it having no legal status. Like Judenrein in Nazi Medicine, it expropriates pseudo-medical terminology to justify massacre. Use of the term dehumanizes the victims as a source of filth and disease, propagates the reversed social ethics of the perpetrators. ${ }^{80}$

Shaw agrees: “Ethnic cleansing' comes without genocide's definite legal prohibition, but it also offers less of a theoretical challenge: it is a minimal, euphemistic term, often adopted for reasons of intellectual as well as political avoidance." 81

During the early 1990s, the term "ethnic cleansing" was frequently used interchangeably with genocide. The World Conference on Human Rights adopted a resolution in 1993 on Bosnia, which stated that "the practice of ethnic cleansing resulting from Serbian aggression against the Muslim and Croat population in the Republic of Bosnia and Herzegovina constitutes genocide in violation of the Convention ..." 82 The Commission of Experts appointed by the Security Council suggested that "ethnic cleansing" could violate the UNCG:

Based on the many reports describing the policy and practices conducted in the former Yugoslavia, "ethnic cleansing" has been carried out by means of murder, torture, arbitrary arrest and detention, extrajudicial executions, rape and sexual assault, confinement of civilian population in ghetto areas, forcible removal, displacement and deportation of civilian population, deliberate military attacks or threats of attacks on civilians and civilian areas, and wanton destruction of property. Those practices constitute crimes against humanity and can be assimilated to specific war crimes. Furthermore, such acts could also fall within the meaning of the Genocide Convention. ${ }^{83}$

Similarly, a UN General Assembly resolution passed on 18 December 1992 denounced the "abhorrent policy of 'ethnic cleansing,' which is a form of genocide." 84 When it was equating "ethnic cleansing" with genocide, the UN was clearly referring to

intensified aggressive acts by the Serbian and Montenegrin forces to acquire more territories by force, characterized by a consistent pattern of gross and systemic violations of human rights, a burgeoning refugee population resulting from mass expulsions of defenseless civilians from their homes and the existence in Serbian and Montenegrin controlled areas of concentration camps and detention centres ... ${ }^{85}$

This view is by no means universal. The eminent genocide scholar William Schabas opines that "ethnic cleansing" is not genocide because the intent is to remove a population, not physically destroy it. ${ }^{86} \mathrm{He}$ further concludes that "the drafters of the Convention quite deliberately resisted attempts to encompass the phenomenon of ethnic cleansing within the punishable acts." 87 Interestingly, Schabas notes that Syria proposed an amendment incorporating a definition of genocide similar to the contemporary notion of "ethnic cleansing": "Imposing measures intended to oblige members of a group to abandon their homes in order to escape the threat of subsequent ill-treatment." 88 Yugoslavia supported the amendment, citing the Nazis' removal of Slav populations from parts of Yugoslavia: "That action was tantamount to the deliberate destruction of a group ... Genocide could be committed by forcing members of a group to abandon their homes ..." 89

The Syrian amendment was defeated, incurring opposition from the United States. The US delegate argued that the Syrian concept "deviated too much from the original concept of genocide." 90 In Prosecutor $v$. Stakic, the rejection of the Syrian proposal was cited by the ICTY Trial Chamber as evidence that "ethnic cleansing" 
was deliberately excluded from the UNCG, ${ }^{91}$ although comments accompanying the Secretariat draft of the convention acknowledge that "[m]ass deportation of populations from one region to another also does not constitute genocide. It would, however, become genocide if the occupation were also attended by such circumstances as to lead to the death of the whole or part of the displaced population ..."92 As Schabas pointedly cautions: "Ethnic cleansing is also a warning of genocide to come ... Genocide is the last resort of the frustrated ethnic cleanser." 93

Although he holds that genocide and "ethnic cleansing" are two different activities, the historian Norman Naimark concedes:

Further complicating the distinctions between ethnic cleansing and genocide is the fact that forced deportation seldom takes place without violence, often murderous violence. People do not leave their homes on their own ... They resist ... The result is that forced deportation often becomes genocidal, as people are violently ripped from their native towns and villages and killed when they try to stay. Even when forced deportation is not genocidal in its intent, it is often genocidal in its effect. ${ }^{94}$

This raises the following questions: Can true "ethnic cleansing" really be achieved without resorting to mass violence and murder? Doesn't "ethnic cleansing," by its very nature, at least imply some component of genocide; such as the mens rea "intent to destroy in whole or in part a national, ethnical, racial or religious group ..."? Is there really a meaningful distinction between intent to "destroy" versus the intent to "cleanse" a territory of a particular group? As Shaw concludes: "It is not just that 'cleansing' is sometimes genocidal, or that genocide is 'extreme' cleansing. Cleansing language invariably oozes genocidal intent, resonating with the idea of destroying, if not murdering, the groups to whom it is applied." 95

Shaw suggests that "expulsion of populations" is a central feature of genocide. ${ }^{96}$ He offers a definition of genocidal conduct as "action in which armed power organizations treat civilian social groups as enemies and aim to destroy their real or putative social power, by means of killing, violence and coercion against individuals whom they regard as members of the groups."97 Shaw's emphasis isn't narrowly focused on the murder of individual members but on destroying a group's economic, political, and cultural power. "Destroying" is understood as inevitably violent, incorporating several power modalities, that is, killing, violence, and coercion. ${ }^{98}$ Accordingly, Shaw's illustration is reminiscent of Lemkin's broader generic concept of genocide.

Of course, adopting too broad a definition of genocide creates the risk of trivializing the term. But "ethnic cleansing" can hardly be considered trivial, especially when accompanied by violence and murder. As Schabas admits, "[B]oth genocide and ethnic cleansing may share the same goal, which is to eliminate the persecuted group from a given area ..."99 Notwithstanding debate over if and when "ethnic cleansing" is genocide, both terms contain similar characteristics that need to be more thoroughly identified and established in the adjudication of genocide.

\section{Adjudicating Genocide}

For genocide to be proved, it must be demonstrated that the perpetrator had the "intent to destroy in whole or in part a national, ethnical, racial or religious group..."100 The specific intent to destroy a protected group has been characterized as the distinguishing feature of genocide: "Thus, for an individual to be guilty of committing genocide, he or she must have an aggravated criminal intent in addition to having the criminal intent accompanying the underlying offense such as killing or causing serious bodily or mental harm to members of the protected group." 101 In 
Prosecutor v. Akayesu, the ICTY Trial Chamber explained that "genocide is distinct from other crimes inasmuch as it embodies a special intent or dolus specialis. Special intent of a crime is the specific intention, required as a constitutive element of the crime, which demands that the perpetrator clearly seeks to produce the act charged." 102 The Trial Chamber further stressed in Prosecutor v. Blagojevic \& Jokic that it is "not sufficient that the perpetrator simply knew that the underlying crime would inevitably or likely result in destruction of the group. The destruction, in whole or in part, must be the aim of the underlying crime(s)."103

Dermot Groome, an ICTY senior prosecutor, contends that this mens rea requirement makes proving genocidal intent particularly difficult: "In many cases the actus reus of genocide may be virtually indistinguishable from the actus reus of other serious international crimes, such as some forms of persecution as a crime against humanity ... Of special note in this context is the determination whether a discriminatory crime was perpetrated against victims because of their membership in a group or was also intended as part of an effort to destroy the group itself."104

This dilemma is further compounded by the collective nature of the crime, involving numerous individuals each with potentially differing motivations and intentions. "It may be that the direct perpetrators harbor genocidal intent, whereas state officials do not. Conversely, the state's senior leaders may be the architects of a carefully calculated genocidal plan that employs a multitude of others as instrumentalities who themselves do not possess genocidal intent," adds Groome. ${ }^{105}$ Accordingly, to determine state culpability, the ICJ had to examine the conduct and motives of individual Serbian actors, and distinguish between genocide and other grievous violations, such as crimes against humanity. In other words, the ICJ had to make similar determinations that were congruently being made by the ICTY, but without the ICTY's rules of procedure and evidence purposefully designed for such inquiry.

Similar to domestic criminal courts, the ICTY is uniquely structured to probe alleged criminal actions and intents of individuals. For example, one prominent feature of the ICTY Statute is the creation of an independent prosecutor's office to fully investigate claims made by all parties. ${ }^{106}$ In contrast, the ICJ has no independent fact finding entity and has to depend primarily upon party submissions. While the ICJ does have some authority to independently request production of evidence, ${ }^{107}$ without the enforcement mechanisms of domestic courts, these provisions are rarely used. This deficiency proved especially daunting when evaluating individual acts of alleged genocide. For instance, the ICJ relied on witness testimony conducted during ICTY proceedings without the benefit of being able to pose questions directly at the deponent. ${ }^{108}$ In short, although designed as a civil forum, the ICJ had to assess the alleged criminal conduct of multiple individuals and entities.

Consequently, this necessitated a dependence on the findings of individual criminal responsibility issued from the ICTY. The ICJ acknowledged this "unusual feature" whereby "[M]any of the allegations before it have already been the subject of the processes and decisions of the ICTY." 109 The Court accepted the "fact-finding process of the ICTY" as "evidence obtained by examination of persons directly involved,' tested by cross-examination, the credibility of which has not been challenged subsequently." ${ }^{110}$ Indeed, Groome warns that having two international courts, with one resolving allegations of State culpability and the other "designed for adjudication of individual crimes," creates separate judicial forums evaluating similar claims with potentially inconsistent results. ${ }^{111}$ This could prove problematic within an international legal system that is horizontally structured. The upshot is 
that the ICJ adopted nearly all factual and legal conclusions of the ICTY, even while applying different legal standards on particular findings.

The second issue is the standard of proof espoused by the Court. Rejecting Bosnia's request that acts of alleged genocide should be proven on the "balance of the probabilities," the Court pronounced that "claims against a State involving charges of exceptional gravity must be proved by evidence that is fully conclusive."112 The ICJ has been critiqued for applying a standard of proof akin to those used in criminal proceedings to a suit that was civil in nature. The Court does not have criminal jurisdiction. Indeed, the ICJ's own opinion concedes that "international law does not recognize the criminal responsibility of the State, and the Genocide Convention does not provide a vehicle for the imposition of such criminal responsibility."113

Although, to assess claims of genocide, the Court did have to make findings that were criminal in nature. Further, the provisions of the UNCG are predominantly criminal, as opposed to the Geneva Conventions that are "mixed." However, while adopting a standard of proof equivalent to that of a criminal trial under these circumstances is arguably defensible, it raises a new set of difficulties. As Groome posits, "Given a standard of proof equivalent to that of a criminal trial for an inquiry that obliges the ICJ to examine the states of minds of individuals not before it, one wonders how an applicant could ever meet that burden." ${ }^{114}$ Stated differently, the ICJ had to ascertain the criminal intent of individuals over whom the Court had no jurisdiction while adhering to a high standard of proof.

Even more disconcerting, however, was that the ICJ did not evaluate all available evidence at its disposal. One oft-cited example was the Court's refusal to consider "redacted" sections of documents from the Supreme Defense Council of Serbia. During the ICTY trial of Slobodan Milosevic, hundreds of documents were produced marked "Defense. State Secret. Strictly Confidential." 115 Described as "incriminating," these documents contained meeting minutes of Yugoslavia's political and military leaders promising "the best inside view of Serbia's role in the Bosnian war ..." 116 However, citing national security concerns, Serbia obtained permission to keep parts of these documents confidential. ${ }^{117}$

The New York Times reported that attorneys who reviewed these documents attested that they demonstrated how Belgrade financed the war. ${ }^{118}$ They reportedly contained evidence that the Bosnian Serb Army (VRS), though officially separate after 1992, remained a de facto extension of the Yugoslav Army, and that "the archives showed in verbatim records and summaries of meetings that Serbian forces, including secret police, played a role in the takeover of Srebrenica and in preparation of the massacre there." 119 Notwithstanding, the ICJ declined to investigate these documents, reasoning that Bosnia already had "extensive documentation and other evidence available to it ..."120 This failure to examine what might have been the most available dispositive evidence of state culpability raises doubts about the Court's conclusion that Serbia did not commit genocide.

Concerns also stem from the criteria used in evaluating the admissible evidence of state complicity. Bosnia alleges that Serbia supplied the VRS with aid and assistance at a time when Serbian authorities were "clearly aware that genocide was about to take place or was underway." ${ }^{121}$ In order to hold Serbia liable for the actions of certain non-de jure organs, including the VRS and several paramilitary entities, some form of state control had to be demonstrated. The ICJ used the "effective control test" instead of the "overall control test" proposed by Bosnia and exercised by the ICTY. "Effective control" requires either that there be "complete dependence" on the controlling authority or that specific "instructions" be given for each operation 
in which violations occur, as opposed to "generally in respect of the overall actions taken by the persons or groups of persons having committed the violations." 122 The ICJ's justification for this higher standard, enunciated in Nicaragua $v$. United States of America ${ }^{123}$ was that "this is the state of customary international law" as reflected in article 8 of the International Law Commission Articles on State Responsibility. ${ }^{124}$

However, as Brunell University law professor Ademola Abass points out, customary international law does not "cast the particular form of that control in stone... The jurisprudence of other international tribunals treats the required control with some degree of flexibility." ${ }^{25}$ For example, the ICTY has found that "the "overall control' test could thus be fulfilled even if the armed forces acting on behalf of the 'controlling state' had autonomous choices and tactics although participating in a common strategy along with the controlling State." 126

In Tadic, the ICTY Appeals Chamber endorsed the "overall control" test by explaining,

The requirement of international law for the attribution to States of acts performed by private individuals is that the State exercise control over the individual. The degree of control may, however, vary according to the factual circumstances of each case. The Appeals Chamber fails to see why in each and every circumstance international law should require a high threshold for the test of control. ${ }^{127}$

While allowing that "overall control" may be the appropriate standard when examining international humanitarian law, the Court's application of the more demanding "effective control" test used to apply a state's responsibility colors the perception of how conclusions were drawn regarding Serbia's role.

For instance, evidence documented from previous tribunal cases illustrate that in late 1993, over 1,800 officers and noncommissioned Yugoslav Army men were also serving in the Bosnian Serb Army while being deployed, paid, or promoted by Belgrade. Top military brass were given dual identities and Belgrade created the 30th Personnel Center described as "a secret office for dealing with officers listed in both armies." 128 The Court even acknowledges that Serbia was "making its considerable military and financial support available to the Republika Srpska, and had it withdrawn that support, this would have greatly constrained the options that were available ..." ${ }^{129}$ Notwithstanding, the ICJ was only willing to find state liability if Belgrade gave direct "instructions" for specific actions or whenever Bosnian Serbs were "completely dependent" upon Belgrade. ${ }^{130}$

As Ruth Wedgwood, an international law professor at Johns Hopkins University, exclaims, "This will be a surprise to scholars of ordinary tort law, who are accustomed to supposing that responsibility can be shared." ${ }^{131}$ Wedgwood also notes that this requirement conflicts with United Nations Security Council Resolution 1373, passed in response to the 11 September 2001 terrorist attacks, confirming that no state can provide intelligence, logistics, or financing to terrorist activities. ${ }^{132}$ In a dissenting opinion, ICJ vice-president Al-Khasawneh concludes: "The inherent danger in such an approach is that it gives States the opportunity to carry out criminal policies through non-state actors or surrogates without incurring direct responsibility therefore." 133

Further, the Court's finding that Serbia did not "control" the relevant forces yet failed to prevent the Srebrenica genocide seems incongruent (implying that Serbia could have prevented the genocide despite not having sufficient control over pertinent actors). With a crime as vast and complex as genocide, it is unlikely that any one participant is going to have "effective control" over certain events. The crime of 
genocide is compounded, requiring coordination and support from multiple sources. Accordingly, article 25(3)(a) of the ICC Statute recognizes the perpetration of a crime through four possible methods of control: direct perpetration; perpetration through another person or indirect perpetration; co-perpetration based on joint control; or indirect co-perpetration. ${ }^{134}$

Indirect control is "applicable when some or all the co-perpetrators carry out their respective essential contributions to the common plan through another person." 135 During the confirmation of charges in the Lubanga and Katanga and Ngudjolo cases, the ICC described complicity based on joint control:

The concept of co-perpetration based on joint control over the crime is rooted in the principle of division of essential tasks for the purpose of committing a crime between two or more persons acting in a concerted manner. Hence, although none of the participants has overall control over the offence because they all depend on one another for its commission, they all share control because each of them could frustrate the commission of the crime by not carrying out his or her task. ${ }^{136}$

The more flexible "control" standards enumerated by both the ICC and the ICTY are in contrast to the ICJ's rigid requirement of direct "instructions" or complete dependence on the controlling authority. Accordingly, the ICJ needs to recognize that "control" can be exercised within varying levels, degrees, and methods.

\section{“Ethnic Cleansing" and Systemic Patterns of Abuse}

Another shortcoming was the ICJ's approach in appraising evidence of a "genocidal pattern." Bosnia sought to demonstrate a consistent pattern of genocidal conduct adduced over a period of years. To do so, the intentions and actions of Serbian political and military leaders had to be assessed. The Court considered a document derived under the auspices of the Bosnian Serb Assembly entitled Decision on the Strategic Goals of the Serbian People in Bosnia and Herzegovina. Bosnia contended that this document indicated that both Radovan Karadzic (president of Republika Srpska from 1992 to 1996) and Milosevic supported the goal of separating Serbia from the "other two ethnic communities." 137

The ICJ's reason for rejecting this argument is twofold: first, the Court maintained that ethnic cleansing alone does not constitute genocide and Bosnia's application failed to "come to terms with the fact that an essential motive of much of the Bosnian Serb leadership-to create a larger Serb State, by a war of conquest if necessary-did not necessarily require the destruction of the Bosnian Muslims and other communities, but their expulsion." ${ }^{138}$ The ICJ cited with approval the ICTY Trial Chamber's holding that "a clear distinction must be drawn between physical destruction and mere dissolution of a group. The expulsion of a group or part of a group does not in itself suffice for genocide."139 While proposing a theoretical hypothesis, this explanation fails to explain what actually did transpire. As Abass inquired: "If the simple goal of Serbia was to simply establish a State of Serbia, as the Court claimed, how then does one account for all the killings that took place?"140

In a separate opinion to the second 1993 provisional order, ad hoc Judge Elihu Lauterpacht reasonably asked, "Has genocide been committed?" He noted that

... the forced migration of civilians, more commonly known as "ethnic cleansing," is, in truth, part of a deliberate campaign by the Serbs to eliminate Muslim control of, and presence in, substantial parts of Bosnia-Herzegovina ... it is difficult to regard the Serbian acts as other than acts of genocide ... they are clearly directed against 
an ethnical or religious group as such, and they are intended to destroy that group, if not in whole certainly in part, to the extent necessary to ensure that the group no longer occupied the parts of Bosnia-Herzegovina coveted by the Serbs. ${ }^{141}$

However, this view was not embraced by the majority of the Court.

Citing a report from the UN Commission of Experts, which concluded that the blockage of humanitarian aid was used to assist the takeover of Sarajevo, the ICJ found that "civilian members of the protected group were deliberately targeted by Serb forces in Sarajevo and other cities ... UNHCR food and fuel convoys had been 'obstructed or attacked by Bosnian Serb and Bosnian Croat forces and sometimes also by governmental forces" "142 Moreover, the ICJ highlighted other instances, for example,

... with regard to Gorazde, the Special Rapporteur found that the enclave was being shelled and had been denied convoys of humanitarian aid for two months. Although food was being air-dropped, it was insufficient ... In a later report, the Special Rapporteur noted that, as of Spring 1994, the town had been subject to a military offensive by Bosnian Serb forces, during which civilian objects including the hospital had been targeted and the water supply had been cut off ... Humanitarian convoys were harassed including by detention of UNPROFOR personnel and the theft of equipment ... Similar patterns occurred in Bihac, Tuzla, Cerska, and Maglaj. ${ }^{143}$

Despite such evidence, the ICJ concluded that the perpetrators did not act with the specific intent to destroy the protected group. The Court placed particular emphasis on the fact that "[t]he Special Rapporteur of the United Nations Commission on Human Rights was of the view that the siege, including the shelling of population centres and the cutting off of supplies of food and other essential goods, is another tactic used to force Muslims and ethnic Croatians to flee." ${ }^{144}$ In other words, according to the ICJ, forcing a particular group to flee did not reflect the intent to destroy. The Court's reasoning was recently cited by the ICC when the Pre-Trial Chamber found insufficient evidence to prosecute al-Bashir, the president of Sudan, for genocide in connection with Darfur. ${ }^{145}$

Second, the ICJ noted that the ICTY made a similar ruling on the same claim, stating that Bosnia's contention "is not consistent with the findings of the ICTY relating to genocide or with the actions of the Prosecutor, including decisions not to charge genocide offences in possibly relevant indictments, and to enter into plea agreements ..."146 The problem with this rationale, however, is that the ICTY was not just settling claims of genocide, it was also resolving allegations of crimes against humanity and war crimes. A prosecutor may exercise discretion, based on various factors, to plea bargain and/or not charge a particular crime. In other words, unlike the ICJ, the ICTY had the option of convicting not just for genocide but also for overlapping violations. Prosecutors have a predilection for charges that will stick, and it is likely easier to obtain a conviction for war crimes or crimes against humanity than for genocide.

Notwithstanding, during the Rule 61 hearing ${ }^{147}$ in Karadzic and Mladic, the ICTY prosecutor offered a description of "ethnic cleansing" that sounds eerily similar to genocide:

Well, ethnic cleansing is a practice which means that you act in such a way that in a given territory the members of a given ethnic group are eliminated. It means a practice that aims at such and such a territory be, as they meant, ethnically pure. So, in other words, the members of the other group are eliminated by different ways, by different methods. You have massacres. Everybody is not massacred, but I mean in 
terms of numbers, you have massacres in order to scare these populations. Sometimes these massacres are selective, but they aim at eliminating the elite of a given population, but they are massacres. I mean, that is the point. So whenever you have massacres, naturally the other people are driven away. They are afraid. They try to run away and you find yourself with a high number of a given people that have been massacred, persecuted and, of course, in the end these people simply want to leave. They are also submitted to such pressures that they go away. They are driven away either on their own initiative or they are deported. But the basic point is for them to be out of that territory and some of them are sometimes locked up in camps. Some women are raped and, furthermore, often times what you have is destruction of the monuments which marked the presence of a given population in a given territory, for instance, religious places, Catholic churches or mosques are destroyed. So basically, this is how ethnic cleansing is practiced in the course of this war. ${ }^{148}$

The prosecutor's summary of "ethnic cleansing" brings to mind Lemkin's broadbased concept of synchronized attacks "on different aspects of the life of the captive peoples ..."149

While the prosecutor was hesitant to pursue charges of genocide, the ICTY recognized that "cleansing" could amount to genocide in certain cases:

The policy of "ethnic cleansing" ... presents, in its ultimate manifestation, genocidal characteristics. Furthermore, in this case, the intent to destroy, in whole or in part, a national, ethnical, racial or religious group, which is specific to genocide, may be inferred from the gravity of the "ethnic cleansing" practiced in Srebrenica and its surrounding areas, i.e., principally the mass killings of Muslims which occurred after the fall of Srebrenica in July 1995, which were committed in circumstances manifesting an almost unparalleled cruelty. ${ }^{150}$

The Brdanin Trial Chamber also acknowledged that "ethnic cleansing may under certain circumstances ultimately reach the level of genocide ..."151 However, the ICJ refused to find that "ethnic cleansing" reached the level of genocide in instances other than in Srebrenica.

Similarly, criticism has been directed at the Court's apparent neglect to properly weigh genocidal proofs in a cumulative manner. Judge Al-Khasawneh had observed that "genocide is definitionally a complex crime in the sense that unlike homicide it takes time to achieve, requires repetitiveness, and is committed by many persons and organs acting in concert. As such, it cannot be appreciated in a disconnected manner. Unfortunately, there are instances in the (Court's) judgment where this happens ..."152 In determining genocidal intent, the ICJ should have more collectively considered its own findings of ethnic cleansing coupled with "evidence of killings of members of the protected group in principal areas of Bosnia [Sarajevo, Drina River Valley, Prijedor, Banja Luka and Brcko] and in various detention camps."153 In addition to Srebrenica, the Court acknowledged "fully conclusive evidence that members of the protected group were systematically victims of massive mistreatment, beatings, rape and torture causing serious bodily and mental harm, during the conflict and, in particular, in the detention camps." ${ }^{154}$ This includes the 1992 killing of civilians in Brcko and the torture and execution of Muslims in Foca. ${ }^{155}$

The Court appears to treat these as separate, isolated episodes rather than as systemic patterns of abuse. While granting that these acts may constitute war crimes and crimes against humanity, the ICJ failed to identify any specific intent to "destroy, in whole or in part, the (protected) group as such." ${ }^{156}$ This narrow reading of the evidence conflicts with ICTY jurisprudence that suggests that proof of genocidal intent "may, in the absence of direct explicit evidence, be inferred from a 
number of facts and circumstances, such as the general context, the scale of atrocities committed, the systematically targeting of victims on account of their membership of a particular group, or the repetition of destructive and discriminatory acts." 157 Accordingly, a more holistic analysis might conclude that acts of genocide occurred in areas outside Srebrenica.

In the end, despite finding "overwhelming evidence that massive killings in specific areas and detention camps throughout the territory of Bosnia and Herzegovina were perpetrated during the conflict" 158 and that "evidence presented shows that the victims were in large majority members of the protected group, which suggests that they may have been systematically targeted by the killings," 159 the only cognizable claim of genocide recognized by the Court was the Srebrenica slaughter. Further, this verdict was limited by the finding that Serbia only failed to prevent genocide, as opposed to it being an accomplice. Furthermore, the ICJ opinion failed to adequately expound upon why the Srebrenica carnage amounted to genocide while other documented instances of inhumanity and mass murder did not. Unfortunately, these defects overshadow an otherwise substantial holding that a nation-state can be held liable under the UNCG and that a state has a duty to prevent genocide.

\section{“Ethnic Cleansing” Revisited}

Croatia's allegations against Serbia were remarkably similar to those of Bosnia. Docketed in 1999, Croatia is suing Serbia for "ethnic cleansing" described as "a form of genocide ..."160 Croatia alleged that Belgrade supported a Croatian Serb insurgency following Croatia's declaration of independence from Yugoslavia in 1991, resulting in killings and displacement of Croatians from the Krajina (an area covering roughly a third of Croatia). ${ }^{161}$ Specifically, Croatia charges stated:

By directly controlling the activity of its armed forces, intelligence agents and various paramilitary detachments, on territory of the Republic of Croatia, in the Knin region, eastern and western Slavonia, and Dalmatia, the Federal Republic of Yugoslavia is liable for the "ethnic cleansing" of Croatian citizens from these areas-a form of genocide which resulted in large numbers of Croatian citizens being displaced, killed, tortured or illegally detained, as well as extensive property destruction-and is required to provide reparation for the resulting damages. In addition, by directing, encouraging, and urging Croatian citizens of Serb ethnicity in the Knin region to evacuate the area in 1995, as the Republic of Croatia reasserted its legitimate governmental authority (and in the face of clear reassurance emanating from the highest level of the Croatian government, including the President of the Republic of Croatia, Dr. Franjo Tudjman, that the local Serbs had nothing to fear and should stay), the Federal Republic of Yugoslavia engaged in conduct amounting to a second round of "ethnic cleansing" in violation of the Genocide Convention. ${ }^{162}$

As a result of Yugoslavia aggression, Croatia alleged,

In Croatia, there were 20,000 dead and 55,000 wounded ... In 1992, the humanitarian crisis in Croatia was at its peak, with approximately 800,000 displaced persons and refugees ... Several thousand Croat civilians were taken prisoner and forcibly transferred to Serbia and other areas ... Of the 7,000 people later released, 60 percent had spent time in prisons or detention facilities ... 1,821 cultural monuments were destroyed or damaged ... 171,000 housing units ... were destroyed ... about 25 per cent of Croatia's total economic capacity ... was damaged or destroyed during $1991-1992 \ldots 163$

Serbia initially threatened to countersue, primarily in connection with the Croatian offensive Operation Storm, launched in August 1995 to recapture the Krajina. Ac- 
cording to Serbia, this resulted in over 200,000 refugees and the murder of civilians left behind. ${ }^{164}$ The Helsinki Committee for Human Rights in Serbia estimated that there were 680 civilian victims. Veritas, a Serbian documentation center, put the figure at nearly 1,200. ${ }^{165}$ According to the ICTY, 350 elderly or ill people were killed by Croat forces. ${ }^{166}$ In February 2004, former Croatian generals Ivan Cermak and Mladen Markac were indicted for crimes against humanity and violations of the laws or customs of war committed in connection with Operation Storm. ${ }^{167}$ They, along with former Croatian general Ante Gotovina, are currently being tried at the ICTY. ${ }^{168}$ At the time of this writing, Serbia has been given until 22 March 2010 to file a response to Croatia's allegations. ${ }^{169}$

A particularly revealing set of developments were the events that lead to the ICTY plea agreement reached with Milan Babic, former president of the selfproclaimed Serb Republic of Krajina (RSK) from 1991 to 1992. The RSK was founded in response to the Croatian declaration of independence. Babic believed that the Serbs in Krajina would become a minority and advocated for the creation of an independent Serbian state. ${ }^{170}$ According to Babic's indictment, between August 1991 through at least June 1992:

Serb forces, comprised of JNA [Yugoslav People's Army], Local Serb TO units from Serbia and Montenegro, Local and Serbian MUP police units, including "Martic's Police," and paramilitary units, attacked and took control of towns, villages and settlements in the SAO [Serbian Autonomous Oblast] Krajina/RSK. After the takeover, Serb forces, in co-operation with the local Serb authorities, established a regime of persecutions designed to drive the Croat and other non-Serb civilian populations from these territories ... According to the 1991 census the total population of the SAO Krajina/RSK was 286,716 . Croats amounted to $78,611(27,42 \%)$ of the total population. Only 1,932 $(0,67 \%)$ Muslims were registered at that time. Virtually the whole Croat, Muslim and non-Serb population of the SOA Krajina/RSK was forcibly removed, deported or killed. ${ }^{171}$

Babic and Slobodan Milosevic were originally allies, but had a falling out over a disagreement of the 1992 cease-fire between Croatia and the insurgency. As a result, Babic was "unceremoniously removed from office at the beginning of 1992 by Serbia's President." 172 In September 2001, Babic was named as a co-perpetrator in the initial ICTY indictment issued against Milosevic. ${ }^{173}$ The following year, Babic voluntarily testified during Milosevic's trial that the former Serbian president exercised political, financial, and military influence over the Serb minority in Croatia. ${ }^{174}$ Whether out of vengeance or remorse, Babic was willing to provide self-incriminating testimony that was "of major significance to the Prosecution's case and substantially reduced its need for further in-depth investigations and presentation of evidence." 175

According to Babic, the Krajina area was underdeveloped and the RSK could not have been sustained without Serbia's financial support. ${ }^{176}$ This testimony was corroborated by former US ambassador to Croatia, Peter Galbraith, who asserted that Krajina was "a completely impoverished region that could not exist even at the very low level that it existed without financial support from Serbia." ${ }^{177}$ Babic further explained,

most of the commanding cadre, commanding staff [in the Croatian Serb Army] were active officers of the JNA who were on the JNA payroll. They were paid by the General Staff of the Yugoslav Army and appointed to those positions by the personnel department of the General Staff of the Yugoslav People's Army. The commanders of the army were appointed by ... Slobodan Milosevic-and it was financed, logistics support was given by Yugoslavia. ${ }^{178}$ 
Babic's indictment, issued in November 2003, contained charges of murder, forced deportation, prolonged and routine imprisonment, and destruction of localities, homes, and cultural institutions. ${ }^{179}$ Pursuant to an agreed upon plea, Babic confessed to acting as a co-perpetrator. The prosecutor recommended a sentence of no more than eleven years, taking into consideration Babic's cooperation in testifying against Milosevic. ${ }^{180}$ Babic was subsequently sentenced to thirteen years, which was confirmed by the Appeals Chamber. ${ }^{181}$ On 5 March 2006 (six days before Milosevic's death), Babic reportedly committed suicide in a prison cell.

Milosevic was ultimately charged on three separate ICTY indictments related to Kosovo, ${ }^{182}$ Bosnia and Herzegovina, ${ }^{183}$ and Croatia. ${ }^{184}$ The Croatia indictment contained thirty-two counts, including criminal responsibility for crimes against humanity, grave breaches of the Geneva Conventions, and violations of the laws and customs of war. (Unlike the Bosnian indictment, ${ }^{185}$ the Croatian indictment did not contain specific charges of genocide. ${ }^{186}$ These acts consisted of a "joint criminal enterprise" calculated to bring about the "forcible removal of the Croat and other non-Serb population ..." ${ }^{187}$ The reference to a "joint criminal enterprise" indicates that the crimes alleged weren't perpetrated by Milosevic alone but in concert with other entities and individuals.

Methods included murder, prolonged imprisonment, creating inhumane living conditions for Croat and other non-Serb civilians in detention centers, torture, the destruction of homes and cultural institutions, and the deportation of "at least 170,000 Croat and other non-Serb civilians ..."188 Although Milosevic died prior to the trial reaching a conclusion, the evidence against the defendant, buttressed by Babic's testimony, will likely be offered to support Croatia's claims against Serbia. Certainly, as president of Serbia during the period in question, Milosevic's actions and motives were relevant to Croatia's allegations.

Notably, pursuant to a Rule 98 hearing, the ICTY found there was sufficient evidence substantiating most counts challenged in the Croatian indictment so that the Trial Chamber could convict Milosevic. ${ }^{189}$ These included charges of persecution, extermination, murder, and killing. ${ }^{190}$ Similar to a summary judgement motion in domestic civil proceedings, a Rule 98bis requires the Court to determine if there is adequate evidence upon which the Trial Chamber could enter a conviction. While the ICJ has held that it doesn't give weight to Rule 98 decisions since they don't constitute a final judgement, ${ }^{191}$ the Court should be willing to independently examine the evidence relied upon by the ICTY.

Consequently, the ICTY also found sufficient evidence to convict Milosevic of genocide in relation to Bosnia's claims. ${ }^{192}$ According to the Trial Chamber, the proofs indicated that the "[a]ccused was the dominant political figure in Serbia and he had profound influence over the Bosnia Serb political and military authorities." 193 This includes evidence that "there was a basic level of support from Serbia to the Bosnian Serbs and in particular to the Bosnian Serb Military. The Bosnian Serb Military emphasized that the chain of command really ran to Belgrade."194 The Court cited testimony from key fact witnesses such as Babic and Galbraith. ${ }^{195}$ The later asserted that Milosevic was "the architect of a policy of creating Greater Serbia and that little happened without his knowledge and involvement." ${ }^{196}$ Despite such potentially conclusive documentation, the ICJ neglected to independently evaluate evidence gleaned from the Milosevic trial. ${ }^{197}$ As Groome concludes: 
... the ICJ should have conducted its own examination of this evidence. Such a review was all the more compulsory in view of the Milosevic trial chamber's finding that the evidence could establish not only that Milosevic, by himself, could be convicted of the crime of genocide, but that he was a member of a joint criminal enterprise comprised of other senior members of the FRY government similarly engaged in genocidal crimes ... ${ }^{198}$

On the surface, it's difficult to fathom the ICJ's arriving at a substantially different conclusion (from the holding reached in Bosnia) with the current Croatian litigation considering the similarities and overlaps between the Croatian and Bosnian claims (i.e., that Serbia committed genocide). At the risk of appearing inconsistent, the Court would need to examine previously overlooked evidence in a more connected fashion and conclude that it rises to the level of genocide. But Milosevic's actions as head of state and his relationship with Babic and other Serbian leaders and entities could be dispositive issues the ICJ will need to resolve in assessing Croatia's allegations. If and how the Court reviews evidence from the Milosevic trial may well influence the outcome.

\section{The Intent to “Destroy"}

Regardless of how the ICJ ultimately rules, the Court should use this opportunity to illuminate when and if evidence of "ethnic cleansing" can satisfy the mens rea intent to "destroy in whole or in part ..." a protected group. What seems paramount to the Bosnia holding is the insistence that the horrific acts described, both alleged and acknowledged, were not accompanied with the specific intent to destroy the protected group. The ICTY reached similar conclusions, writing that

the dolus specialis has not been proved in relation to "deliberately inflicting on the group conditions of life calculated to bring about its physical destruction in whole or in part." The Trial Chamber recalls in this context that deporting a group or part of a group is insufficient if it is not accompanied by methods seeking the physical destruction of the group. ${ }^{199}$

But must the "intent" element be required to correlate directly to the prohibited acts contained in article 2 of the UNCG, or should intent be interpreted more broadly to include motivation to destroy the protected group as a social unit?

As noted, the ICTY also did not find genocidal intent despite evidence of "ethnic cleansing." 200 However, the ICTY Trial Chamber in Prosecutor v. Kristic instructively cited the Federal Constitutional Court of Germany, which stated that

the statutory definition of genocide defends a supra-individual object of legal protection, i.e., the social existence of the group ... the intent to destroy the group ... extends beyond physical and biological extermination ... The text of the law does not therefore compel the interpretation that the culprit's intent must be to exterminate physically at least a substantial number of the members of the group ... 201

While the Trial Chamber declined to fully endorse this approach, the Court acknowledged that "where there is physical or biological destruction there are often simultaneous attacks on the cultural and religious property and symbols of the targeted group as well, attacks which may legitimately be considered as evidence of an intent to physically destroy the group." 202 


\section{The Appeals Chamber in Krstic allowed that}

[t]he fact that the forcible transfer does not constitute in and of itself a genocidal act does not preclude a Trail Chamber from relying on it as evidence of the intentions of members of the VRS Main Staff. The genocidal intent may be inferred, among other facts, from evidence of "other culpable acts systematically directed against the same group."203

These dicta hint at a coherent method in evaluating genocidal intent: the perpetrator does not have to intend to commit genocide per se. Intention is satisfied when the goal is to "destroy" a protected group, broadly understood. While the complete definition of "genocide" may require physical or biological destruction (i.e., killing), methods aimed at "destroying" a protected group should not be so narrowly construed. There are multiple ways that a protected group can be destroyed as a social unit (i.e., "ethnic cleansing"). If, in the process, a prohibited act under the UNCG is carried out, then evidence of genocide is demonstrated.

A more expansive approach at analyzing intent was embraced by the European Court of Human Rights in Jorgic $v$. Germany. ${ }^{204}$ The Higher Regional Court at Dusseldorf convicted Nicolai Jorgic, a Bosnian Serb, of eleven counts of genocide, which included the murder of thirty people. The Court held that the "intent to destroy" did not "necessitate an intent to destroy that group in a physical or biological sense. It was sufficient that the perpetrator aimed at destroying the group in question as a social unit." ${ }^{205}$ After the conviction was upheld on appeal, Jorgic pleaded to the European Court of Human Rights that the exercise of universal jurisdiction violated article 6 of the European Convention on Human Rights.

In rejecting the defendant's application, the European Court examined the meaning of the phrase "intent to destroy" as contained in article 220a of Germany's Criminal Code dealing with genocide. The Court noted that the wording of article 2 of the UNCG corresponds to article 220a of the Criminal Code, which interprets "the Genocide Convention so as to comprise the protection of a group as a social unit."206 Accordingly, the Court concluded that

the domestic courts' interpretation of "intent to destroy a group" as not necessitating a physical destruction of the group, which has also been adopted by a number of scholars ..., is therefore covered by the wording, read in its context, of the crime of genocide in the Criminal Code and does not appear unreasonable. ${ }^{207}$

In contrast to the European Court, the ICJ postulated that

the intent that characterizes genocide is "to destroy, in whole or in part" a particular group, and deportation or displacement of the members of a group, even if effected by force, is not necessarily equivalent to destruction of that group, nor is destruction an automatic consequence of displacement. This is not to say that acts described as "ethnic cleansing" may never constitute genocide, if they are such as to be characterized as, for example, "deliberately inflicting on the group conditions of life calculated to bring about its physical destruction in whole or in part," contrary to Article II, paragraph c, of the Convention, provided such action is carried out with the necessary specific intent (dolus specialis), that is to say with a view to the destruction of the group, as distinct from its removal from the region. ${ }^{208}$

The Court's interpretation is problematic. First, it appears to define "destruction of the group" as limited to physical destruction. Second, when "ethnic cleansing" gives rise to murder, the resultant killing is not happenstance. The "intent to destroy" (a "substantial" portion of $)^{209}$ a protected group is only one component of genocide. 
Committing a prohibited act, such as murder, completes the criminal definition. There are many ways a protected group can be "destroyed." Interpretation of the UNCG should not require the intent to carry out "genocide" per se, but rather the intent to "destroy" the social unit of a protected group. If, in the process, a prohibited act such as murder is contemporaneously performed, then genocide can be inferred.

As noted, the judicial inquiry raised is whether the required "intent to destroy" should be interpreted to strictly refer to the prohibited acts defined by the UNCG. As Schabas explains, "an important problem of interpretation arises as to whether the destruction that is part of the intent, in the first part of article II, must correspond to the physical or biological destruction defined in the second part of article II."210 Schabas points out that the International Law Commission considered this issue during the drafting of the Code of Crimes and concluded:

As clearly shown by the preparatory work for the Convention, the destruction in ques-
tion is the material destruction of a group either by physical or biological means, not
the destruction of the national, linguistic, religious, cultural or other identity of a
particular group. The national or religious element and racial or ethnic element are
to be taken into consideration in the definition of the word "destruction," which must
be taken only in its material sense, its physical or biological sense. It is true that the
1947 draft Convention prepared by the Secretary-General and the 1948 draft pre-
pared by the ad hoc Committee on Genocide contained provisions on "cultural geno-
cide" covering any deliberate act committed with the intent to destroy the language,
religion or cultural of a group, such as prohibiting the use of language of a group in
daily intercourse or in schools or the printing and circulation of publications in the
language of the group or destroying or preventing the use of libraries, museums,
schools, historical monuments, places of worship or other cultural institutions and
objects of the group. However, the text of the Convention, as prepared by the Sixth
Committee and adopted by the General Assembly, did not include the concept of
"cultural genocide' contained in the two drafts and simply listed acts which come
within the category of "physical" or "biological" genocide.

However, when physical or biological destruction is perpetrated in the context of "ethnic cleansing" or some type of "cultural genocide," are courts to presume such destruction to be incidental? Does this interpretation make sense in the face of widespread violence, murder, and abuse? If so, can evidence of "ethnic cleansing" be used to actually refute genocide claims? (For example, the ICJ relying on the Special Rapporteur's conclusion that cutting off food supplies was motivation enough to cause Muslims and Croatians to flee. $)^{212}$ These results certainly do not mirror the letter and spirit of the UNCG. As Schabas succinctly considers:

A court seeking to adopt the broader and more liberal view [of intent] could, however, rely on the text itself, the objectives of the Convention, the need for dynamic interpretation of legal instruments that protect human rights, and the principle established in the Vienna Convention on the Law of Treaties which authorizes resort to a convention's preparatory work only when the ordinary meaning of the provision, taken in its context and in light of its object and purpose, leaves a provision "ambiguous or obscure." 213

Absent careless negligence, the broader interpretation suggested in Jorgic, is the only logical application when the "intent to destroy" culminates in genocidal conduct.

Instructively, this is underscored in Blagojevic, where the ICTY Trial Chamber recognized the "ethnic cleansing" objective behind the Srebrenica massacre: 
Immediately before and during these massacres, the remainder of the Bosnian Muslim population of Srebrenica was forcibly transferred to Bosnian Muslim-held territory. The forcible transfer of the women, children and elderly is a manifestation of the specific intent to rid the Srebrenica enclave of its Bosnian Muslim population. The manner in which the transfer was carried out-through force and coercion, by not registering those who were transferred, by burning the houses of some of the people, sending the clear message that they had nothing to return to, and significantly, through its targeting of literally the entire Bosnian Muslim population of Srebrenica, including the elderly and children-clearly indicates that it was a means to eradicate the Bosnian Muslim population from the territory where they had lived. ${ }^{214}$

Further, it is unlikely that the architects of the UNCG could have anticipated all the subsequent conditions which have produced genocidal violence. Provocatively, Shaw questions whether changes in historical trends affect the very nature and perception of genocide: "Is the problem posed differently today compared with the period when the concept [of genocide] was developed? ... Are the forms of genocide changing? Are there significant patterns in these changes at the beginning of our new century? And has the conceptual proliferation [i.e., the term 'ethnic cleansing'] represented attempts, confused perhaps, to register historical transformation?"215

Shaw's point is that the nature of genocide is not fixed or static. It is multifaceted, comprehensive, and variable. While it is unlikely that international courts will adopt a broader definition of genocide beyond the parameters of the UNCG, they need to articulate an understanding of genocidal intent that accounts for changing circumstances and methods. The "intent to destroy" can manifest in many ways. "Ethnic cleansing" might demonstrate such intent, and when accompanied by a prohibited act such as killing, a finding of genocide should be judicially permitted.

\section{Conclusion}

The Bosnian genocide case is arguably the most complex matter the ICJ has ever presided over. To determine state culpability, the ICJ had to assess individual criminal actions, a task for which it was ill-suited, ensuring a relationship of dependency with findings of the ICTY. Difficulties were further exacerbated by questionable methods over what and how to evaluate evidence. Furthermore, the context of ongoing civil strife presented explicit compliance problems that rendered provisional edicts ineffective. Since the ICJ is the only Court with jurisdiction over nation-states (the ICC and ICTY have jurisdiction over individuals), it is likely that state responsibility will continue to be contested in this forum when allegations of genocide arise. Accordingly, reform measures could bolster the Courts ability to analyze complex facts and better ascertain evidential findings.

Since the ICJ is a court of both first and last impression, it must make dual findings of fact and law. The Court would benefit from a separate fact-finding commission to evaluate evidential proofs "when the facts and their elucidation are paramount." 216 If designed as a hybrid entity, this body can incorporate characteristics similar to both a domestic trial court and prosecutor's office, with powers of subpoena and the ability to evaluate witness/expert testimony. The ICJ can then more appropriately concern itself with rendering legal opinions based on the facts presented by the commission. Susan SáCouto, director of the War Crimes Research Office at American University, suggests that such a commission might be useful in providing preliminary analysis of the best available evidence. ${ }^{217}$

Similarly, an alternative proposal is to modify the Court's rules to provide for a special master to assist with making factual findings. ${ }^{218}$ The US Supreme Court has 
a comparable modus operandi in matters of original jurisdiction. This might aid the Court with analyzing pertinent evidence in a more precise fashion. Such reforms could assist with identifying systemic patterns of abuse, adduced over a period of time, suggestive of genocidal intent. In addition, it might result in less dependency on the corresponding work of other courts.

Meanwhile, the significance of the ICJ's bold ruling establishing an affirmative duty for nation-states to prevent genocide, to the extent possible, must not be overlooked. Historically, genocide is virtually always carried out with implicit knowledge and/or assistance from state authority. ${ }^{219}$ Providing a cause of action against these states could both discourage state complicity with genocidal acts and encourage measures to pro-actively prevent such acts from developing. This prospect is particularly noteworthy considering the apparent ineffectiveness of the ICJ's interim measures. The duty to prevent is an important legal principle that will continue to evolve in international law. ${ }^{220}$

As originally proposed, the term genocide conveyed not just mass killings but also methods designed to dilute a group's economic, political, and cultural power. The meaning of genocide has subsequently been more narrowly construed to denote only conduct calculated to bring about biological or physical destruction, as defined by the prohibited acts contained in article 2 of the UNCG. Given the many ways an unwanted group can be targeted, justice would be better served if courts considered the broader sociological concept advocated by Lemkin. This could be achieved, not by expanding the list of specific prohibited acts, but through interpreting the "intent to destroy" so that it includes measures aimed at disrupting the protected group as a social unit.

While conceived in the aftermath of the Nazi-driven Holocaust, the UNCG has been interpreted against the backdrop of changing international conditions and diverse methods of repression. Techniques and circumstances may vary, but the intent to "destroy" a particular group, broadly understood, remains the distinguishing feature of both genocide and related humanitarian crimes such as "ethnic cleansing." The role that this plays in adjudicating claims of genocide needs to be further established. In Croatia, the ICJ has another opportunity to elaborate on the nexus between "ethnic cleansing" and genocidal intent. Such a contribution will better reflect the realities of how genocide can unfold in the twenty-first century.

\section{Acknowledgments}

The author wishes to thank Professor Lung-chu Chen, from New York Law School, for helpful comments made in connection with this article.

\section{Notes}

1. Croatia v. Serbia, 2008 I.C.J. 118 (Judgment on Preliminary Objections), 18 November 2008.

2. Croatia v. Serbia, 2008 I.C.J. 118, Application of the Convention on the Prevention and Punishment of the Crime of Genocide (Application Instituting Proceedings), 2 July 1999, para. 2.

3. Convention on the Prevention and Punishment of the Crime of Genocide, 9 December 1948, 78 U.N.T.S. 277, http://www2.ohchr.org/english/law/genocide.htm (accessed 14 January 2010).

4. Application of the Convention on the Prevention and Punishment of the Crime of Genocide (Bosnia and Herzegovina v. Serbia and Montenegro), 2007 I.C.J. 140 (26 February 2007) [Bosnian Genocide]. 
5. Ibid., para. 430.

6. See Susana SáCouto, "Reflections on the Judgment of the International Court of Justice in Bosnia's Genocide Case against Serbia and Montenegro," Human Rights Brief 15 (2007): 2-6.

7. See Dermot Groome, "Adjudicating Genocide: Is the International Court of Justice Capable of Judging State Criminal Responsibility?" Fordham International Law Journal 31 (2008), 911.

8. Charter of the United Nations, 26 June 1945, art. 92, T.S. No. 993, 3 Bevans 1153 [UN Charter].

9. Statute of the International Court of Justice, Annex to the UN Charter, 26 June 1945, Arts. 4-10, 13.1, 59 Stat. 1055, T.S. No. 993, 3 Bevans 1179 (1945) [ICJ Statute].

10. Ibid., art. 34.1.

11. UN Charter, art. 96; ICJ Statute, art. 65.

12. ICJ Statute, art. 41.

13. "Jurisdiction" refers to the authority of a court to decide on a subject matter over certain litigants.

14. Eric A. Posner and Miguel F.P. de Figueiredo, "Is the International Court of Justice Biased?" Journal of Legal Studies 34 (2005): 599-628, 603.

15. ICJ Statute, art. 36(1).

16. ICJ Statute, art. 36(2).

17. See Richard Graving, "The International Court of Justice Muddles Jurisdiction in Yugoslav Genocide Case," Tulsa Journal of Comparative and International Law 15 (2007): 29-59, 33-34.

18. Karin Oellers-Frahm, "Article 94 UN Charter," in The Statute of the International Court of Justice: A Commentary, ed. Andreas Zimmerman, Christin Tomuschat, and Karin Oellers-Frahm, 174-75 (New York: Oxford University Press, 2006).

19. Jonathan I. Charney, "Disputes Implicating the Institutional Credibility of the Court: Problems of Non-appearance, Non-participation, and Non-performance," in The International Court of Justice at a Crossroads, ed. Lori F. Damrosch, 288-319 (Ardsley, NY: Transnational Publishers, 1987), 288.

20. Colter Paulson, "Compliance with Final Judgments of the International Court of Justice since 1987," American Journal of International Law 98 (2004): 434-61, 460.

21. Ibid.

22. See Constanze Schulte, Compliance with Decisions of the International Court of Justice (New York: Oxford University Press, 2004).

23. Ibid., 413.

24. Ibid., 419.

25. Shabtai Rosenne, The World Court: What It Is and How It Works, 5th ed. (Dordrecht: Martinus Nijhoff, 1995), 113-53.

26. Ibid., 170-72 (Namibia); 199-200 (Northern Cameroons); 232-33 (Nauru); 234-35 (East Timor).

27. Ibid., 170-72 (Ethiopia v. South Africa and Liberia v. South Africa).

28. Ibid., 164-66 (Colombia v. Peru).

29. Ibid., 215-17 (US diplomatic hostages in Tehran).

30. Ibid., 204-206 (Pakistani POWs).

31. Ibid., 225-27.

32. Ibid., 158-60 (membership in UN) (two opinions); 183-85 (UN administrative tribunals) (five opinions); 197-98 (Maritime Safety Committee); 200-02 (UN peacekeeping budget).

33. Ibid., 168-75 (Namibia) (three opinions); 213-5 (Western Sahara).

34. Ibid., 176-77 (genocide); 233-34 (rapporteur).

35. Legality of the Use of Nuclear Weapons in Armed Conflict, 1996 I.C.J. 93 (July 8) (Judgment on preliminary objections); Legality of the Threat or Use of Nuclear Weapons, 1996 I.C.J. 95 (8 July). 
36. Legal Consequences of the Construction of a Wall in the Occupied Palestinian Territory, Advisory Opinion, 43 I.L.M. 1009 (9 July).

37. Vienna Convention on Consular Relations (Para v. U.S.), 1998 I.C.J. 99 (9 April) (removed from list by Order of 10 November 1998); LaGrand, 2001 I.C.J.104 (27 June); Mexico v. U.S., 2003 I.C.J. 128 (9 January).

38. Legality of Use of Force: Serbia and Montenegro v. Belgium, 1999 I.C.J. 105; Serbia and Montenegro v. Canada, 1999 I.C.J. 106; Serbia and Montenegro v. France, 1999 I.C.J. 107; Serbia and Montenegro v. Germany, 1999 I.C.J. 108; Serbia and Montenegro v. Italy, 1999 I.C.J. 109; Serbia and Montenegro v. Netherlands, 1999 I.C.J. 110; Serbia and Montenegro v. Portugal, 1999 I.C.J. 111; Yugoslavia v. Spain, 1999 I.C.J. 112; Yugoslavia v. United States of America, 1999 I.C.J. 114.

39. Armed Activities on the Territory of the Congo (Dem. Rep. Congo v. Uganda), 2006 I.C.J. 126 (3 February 2006).

40. Neil MacFarquhar, "Serbia Wins Bid to Review Independence of Kosovo," The New York Times, 9 October 2008, A10.

41. Application of the Convention on the Prevention and Punishment of the Crime of Genocide (Bos. \& Herz. V. Yug. [Serb. \& Mont.]), 1993 I.C.J.91 (20 March).

42. Marc Weller, "The International Response to the Dissolution of the Socialist Federal Republic of Yugoslavia," American Journal of International Law 86 (1992): 569-607, $570,593,594$.

43. Virginia Morris and Michael P. Scharf, An Insider's Guide to the International Criminal Tribunal for the Former Yugoslavia: A Documentary History and Analysis (Ardsley, NY: Transnational Publishers, 1996), 19.

44. Misha Glenny, The Fall of Yugoslavia: The Third Balkan War (New York: Penguin, 1993), 181-234.

45. Morris and Scharf, An Insider's Guide, 20.

46. Ibid., 21-22; Letter Dated 9 February 1993 from the Secretary-General Addressed to the President of the Security Council, U.N.SCOR, 48th Sess., Annex 1, para. 55-63, UN Doc. S/25274 (1993).

47. Interim Report of the Commission of Experts Established Pursuant to Security Council Resolution 780 (1992), UN Doc. S/35374 (1993), para 55.

48. Situation of Human Rights in the Territory of the Former Yugoslavia, UN Doc. E/CN.4/ 1993/50 (10 February 1993), para. 17.

49. Ibid., para. 18.

50. Ibid., paras. 20, 22 .

51. Ibid., para. 85 (emphasis added).

52. Bosnia Genocide, 2007 I.C.J., paras. 323-28, 335-44.

53. Christopher S. Wren, "Resettling Refugees: U.N. Facing New Burden," The New York Times, 24 November 1995, A15.

54. Marlise Simons, "Court Declares Bosnia Killings WereGenocide," The New York Times, 27 February 2007, http://www.nytimes.com/2007/02/27/world/europe/27hague.html (accessed 21 January 2010).

55. Ibid.

56. Foreign Military Studies Office, U.S. Army Combined Arms Center, Ft. Leavenworth, Kansas \& Center for Military-Strategic Studies, General Staff of the Armed Forces, Moscow, Russia, Lessons and Conclusions on the Execution of IFOR Operations and Prospects for a Future Combined Security System: The Peace and Stability of Europe after IFOR 3-6 (1999).

57. General Framework Agreement for Peace in Bosnia and Herzegovina, 14 December 1995, 35 I.L.M. 75 (1996).

58. Application of the Convention on the Prevention and Punishment of the Crime of Genocide (Bosnia \& Herzegovina v. Yugoslavia (Serbia \& Montenegro)), 1993 I.C.J. 376-89 (13 September) (separate opinion of Judge Weeramantry).

59. Security Council Res. 808, Preamble, UN Doc. S/RES/808 (22 February 1993); S.C. Res. 827, Preamble, UN Doc. S/RES/827 (25 May 1993). 
60. UN, International Criminal Tribunal for the Former Yugoslavia, "About the ICTY," http://www.icty.org/sections/AbouttheICTY (accessed 21 January 2010).

61. Bosnian Genocide, 2007 I.C.J., para. 147.

62. Ibid.

63. ICTY Statute, arts. 2-5.

64. John Quigley, "International Court of Justice as a Forum for Genocide Cases," Case Western Reserve Journal of International Law 40 (2007/8): 243-63, 244.

65. Antonio Cassesse, "Genocide," in The Rome Statute of the International Criminal Court: A Commentary, vol. 1, ed. Antonio Cassesse, Paola Gaeta, and John R.W.D. Jones (New York: Oxford University Press, 2002), 335. Also, note that prior to the UNCG, genocide was classified as a crime against humanity.

66. See World Signatures and Ratifications, Coalition for the International Criminal Court, http://www.iccnow.org/?mod=romesignatures\&phpsessid=

a3059fa7b19c68b6clce4a8263613754 (listing country signature and ratification dates of the Rome Statute).

67. G.A.Res. 96/1, UN Doc. A/RES/96/1 (11 December 1946).

68. UNCG, art. 2.

69. Roman Serbyn, "Lemkin on Genocide of Nations," Journal of International Criminal Justice 7 (2009): 123-30.

70. Ibid.

71. Raphael Lemkin, Axis Rule in Occupied Europe: Laws of Occupation, Analysis of Government, Proposals for Redress (Washington, DC: Carnegie Endowment for International Peace, 1944), xi-xii.

72. Martin Shaw, What Is Genocide? (Cambridge: Polity Press, 2007), 20.

73. Alberto Costi, "The 60th Anniversary of the Genocide Convention," Victoria University of Wellington Law Review 39 (2008): 831-49, 838.

74. Shaw, What Is Genocide? 33.

75. Ibid., 63-78.

76. Andrew Bell-Fialkoff, "A Brief History of Ethnic Cleansing," Foreign Affairs (Summer 1993), http://www.foreignaffairs.com/articles/48961/andrew-bell-fialkoff/a-brief-history-ofethnic-cleansing (accessed 14 January 2010).

77. F. Chalk and K. Jonassohn, The History and Sociology of Genocide: Analyses and Case Studies (New Haven, CT: Yale University Press, 1990), 1 (emphasis added).

78. Rome Statute of the International Criminal Court, (2002) 2187 U.N.T.S. 90, art. 7(2)(d).

79. Rony Blum et al., “Ethnic Cleansing' Bleaches the Atrocities of Genocide," European Journal of Public Health 18 (2007): 204-9.

80. Ibid., 204.

81. Shaw, What Is Genocide? 37.

82. UN Doc. A/CONF.157/24 (Part 1), 47-48.

83. "Interim Report of the Commission of Experts Established Pursuant to Security Council Resolution 780 (1992)," note 281, para. 56. See also William Schabas, Genocide in International Law, 2nd ed. (Cambridge: Cambridge University Press, 2009), 224 (emphasis added).

84. 'The Situation in Bosnia and Herzegovina," UN Doc. A/RES/47/121 (emphasis added).

85. Ibid.

86. Schabas, Genocide in International Law, 233.

87. Ibid., 227.

88. Ibid., 228.

89. Ibid.

90. Ibid.

91. Prosecutor v. Stakic, Judgment, ICTY-97-24-T (31 July 2003), para. 519. See also Case Concerning the Application of the Convention on the Prevention and Punishment of the Crime of the Crime of Genocide (Bosnia and Herzegovina v. Serbia and Montenegro), Judgment (26 February 2007), para. 190. 
92. UN Doc. E/447, 24.

93. Schabas, Genocide in International Law, 234.

94. Norman M. Naimark, Fires of Hatred: Ethnic Cleansing in Twentieth-Century Europe (Cambridge, MA: Harvard University Press, 2001), 3-4, cited in Shaw, What Is Genocide? 53 (emphasis added).

95. Shaw, What Is Genocide? 58.

96. Ibid., 61.

97. Ibid., 154.

98. Ibid., 156.

99. Schabas, Genocide in International Law, 234.

100. UNCG, art. 2 .

101. Stefan Kirsch, "The Two Notions of Genocide: Distinguishing Macro Phenomena and Individual Misconduct," Creighton Law Review 42 (2009): 347-60; Presentation at the International Conference Commemorating the 60th Anniversary of the Genocide Convention, Philipps-Universitat, Marburg, Germany, 3-6 December 2008), 351 (emphasis added).

102. Prosecutor v. Akayesu, Judgment, ICTR-96-4-T (2 September 1998), para. 498, cited in Kirsch, "Two Notions of Genocide," 351.

103. Prosecutor v. Blagojevic \& Jokic, Judgment, ICTY-02-60-T (17 January 2003), para. 656, cited in Kirsch, "Two Notions of Genocide," 351 (emphasis added).

104. Groome, "Adjudicating Genocide," 918, 919.

105. Ibid., 920.

106. ICTY Statute, art. 16.

107. Groome, "Adjudicating Genocide," 981: "The ICJ has the power to apply directly to governments who are not parties to serve notices upon persons in possession of evidence. It can require agents of the parties before it to produce documentary evidence and can call upon the parties to produce evidence. The ICJ can proprio motu visit locations related to the case in order to obtain evidence itself. While in theory these provisions give the ICJ some of the mechanisms available to an international prosecutor or international criminal court to secure evidence, the ICJ's customary practice has been to exercise these powers infrequently and to depend upon the parties for the production of evidence."

108. Ibid., 988.

109. Bosnian Genocide, 2007 I.C.J., para. 212.

110. Ibid., para. 214.

111. Groome, "Adjudicating Genocide," 979.

112. Bosnian Genocide, 2007 I.C.J., para. 209 (emphasis added).

113. Ibid., para. 170.

114. Groome, "Adjudicating Genocide," 934.

115. Marlise Simons, "Genocide Court Ruled for Serbia without Seeing Full War Archive," New York Times, 9 April 2007, http://www.nytimes.com/2007/04/09/world/europe/09archives. html?_r=1\&pagewanted=all (accessed 21 January 2010).

116. Ibid.

117. Ibid.

118. Ibid.

119. Ibid.

120. Bosnian Genocide, 2007 I.C.J., para. 206.

121. Ibid., para. 422 .

122. Ibid., para. 400 .

123. Military and Paramilitary Activities (Nicaragua v. U.S.), 1986 I.C.J. 14 (27 June).

124. Bosnian Genocide, 2007 I.C.J., para. 401.

125. Ademola Abass, "Proving State Responsibility for Genocide: The ICJ in Bosnia v. Serbia and the International Commission of Inquiry for Darfur," Fordham International Law Journal 31 (2008): 871-910, 894.

126. Prosecutor v. Delalic, ICTY-96-21-A (20 February 2001), para. 47,cited in Abass, "Proving State Responsibility for Genocide," 894. 
127. Prosecutor v. Tadic, Judgment, ICTY-94-1-A (15 July 1999), 117, cited in Abass, "Proving State Responsibility for Genocide," 894 (emphasis added).

128. Simons, "Genocide Court Ruled for Serbia."

129. Bosnian Genocide, 2007 I.C.J., para. 241.

130. Ibid., 400 .

131. Ruth Wedgwood, "Slobodan Milosevic's Last Waltz," The New York Times, 12 March 2007, http://www.nytimes.com/2007/03/12/opinion/12wedgwood.html?_r=1\&pagewanted=all (accessed 21 January 2010).

132. Ibid.

133. Bosnian Genocide, Dissenting Opinion of Vice-President Al-Khasawneh, 2007 I.C.J., para. 39.

134. ICC-01/04-01/06-803-eTN, para. 330.

135. ICC-02/05-01/09, para. 213.

136. ICC-01/04-01/06-803-tEN, para. 342 (emphasis added). See also ICC-01/04-01/07-717, para. 521; ICC-02/05-01/09, para. 212.

137. Bosnian Genocide, 2007 I.C.J., para. 371.

138. Ibid., para. 372 .

139. Ibid., para.190, citing Stakic, Judgment, para. 519.

140. Abass, "Proving State Responsibility for Genocide," 899.

141. Application of the Convention on the Prevention and Punishment of the Crime of Genocide (Bosnia and Herzegovina v. Yugoslavia (Serbia and Montenegro), Further Requests for the Indication of Provisional Measures, 13 September 1993, Separate Opinion of Judge Lauterpacht, para. 69 (emphasis added).

142. Bosnian Genocide, 2007 I.C.J., paras 328, 324.

143. Ibid., para. 327.

144. Ibid., para. 328 .

145. ICC-02/05-01/09, 4 March 2009, paras. 181, 182, 183.

146. Bosnian Genocide, 2007 I.C.J., para. 374.

147. The Rule 61 hearing is described as a "public reminder" that the accused are wanted for serious violations of international law and assists in developing an historical record of the atrocities. See http://www.icty.org/sid/7397.

148. Prosecutor v. Karadzic et al., Transcript of Hearing, ICTY-95-18-R61 and ICTY-95-5-R61 (28 June 1996), 10. See also Schabas, Genocide in International Law, 222.

149. Lemkin, Axis Rule in Occupied Europe, xi.

150. Prosecutor $v$. Karadzic and Mladic, Confirmation of Indictment, ICTY-95-18-I (16 November 1995) (emphasis added). See also Shaw, What Is Genocide? 51.

151. Prosecutor v. Brdanin, Judgment, ICTY-99-36-T (1 September 2004), para. 977, n. 2455.

152. Bosnian Genocide, Dissenting Opinion of Vice-President Al-Khasawneh, 2007 I.C.J., para. 48.

153. Bosnian Genocide, 2007 I.C.J., para. 245.

154. Ibid., para. 319 (emphasis added).

155. Wedgwood, "Slobodan Milosevic's Last Waltz."

156. Bosnian Genocide, 2007 I.C.J., para. 319.

157. Prosecutor v. Jelisic, Judgment, ICTY-95-10-A (5 July 2001), para. 47.

158. Bosnian Genocide, 2007 I.C.J., para. 276.

159. Ibid.

160. Croatia v. Serbia, 2008 I.C.J. 118, Application by the Republic of Croatia Instituting Proceedings Against the Federal Republic of Yugoslavia, 2 July 1999, para. 2.

161. Zoran Radosavljevic, "Factbox-Brief History of Croatia's Rebel Serb Krajina Region," Reuters UK, 11 March 2008.

162. Croatia v. Serbia, 2008 I.C.J. 118, para. 2.

163. Ibid., para. 17.

164. Matt Prodger, "Evicted Serbs Remember Storm," BBC News, 8 May 2005, http://news. bbc.co.uk/2/hi/europe/4747379.stm (accessed 14 January 2010); Goran Jungvirth, "Serbia 
Angles for Croatia to Drop Genocide Case," Human Rights Tribune, 9 April 2009, http:// www.humanrights-geneva.info/serbia-angles-for-croatia-to-drop,4330 (accessed 14 January 2010).

165. “Serbia to Counter-sue Croatia for War Crimes," France 24, 18 November 2008, http:// www.france24.com/en/20081118-un-court-hear-genocide-claim-against-serbia-croatiajustice (accessed 21 January 2010).

166. Ibid.

167. Prosecutor v. Ivan Cermak and Mladen Markac, ICTY-03-73.

168. Ibid.

169. Croatia v. Serbia, 2008 I.C.J. 118, Order of 20 January 2009.

170. Prosecutor v. Babic, Sentencing Judgment, ICTY-03-72-S (29 June 2004), paras. 20, 23.

171. Prosecutor v. Babic, Initial Indictment, ICTY-03-72-S (6 November 2003), paras. 5, 14, $15 \mathrm{c}$ (emphasis added).

172. Gabriel Partos, "Milan Babic: Leader of a Serb Mini-State, Krajina, Who Was Sacked by Milosevic and Then Gave Evidence against Him," The Independent, 7 March 2006, http://www.independent.co.uk/news/obituaries/milan-babic-468887.html (accessed 14 January 2010).

173. Cited in "Judgment in the Case The Prosecutor v. Milan Babic: Milan Babic Sentenced to 13 Years' Imprisonment" (Press release, 29 June 2004), http://www.icty.org/x/cases/ babic/tjug/en/040629_Babic_summary_en.pdf (accessed 21 January 2010).

174. Partos, "Milan Babic."

175. Babic, Sentencing Judgment, para. 73, quoting the Prosecution Sentencing Brief, para. 44.

176. Prosecutor $v$. Milosevic, Testimony of Milan Babic, Trial Transcript, ICTY-02-54-T (19 November 2002), 12970-71.

177. Prosecutor v. Milosevic, Testimony of Peter Galbraith, Trial Transcript, ICTY-02-54-T (25 June 2003), 23087.

178. Prosecutor v. Milosevic, Testimony of Milan Babic, Trial Transcript, ICTY-02-54-T (21 November 2002), 13234.

179. Babic, Initial Indictment, paras. 14, 15.

180. "Judgment in the Case The Prosecutor v. Milan Babic.".

181. Prosecutor v. Babic, Appeals Chamber Judgment, ICTY-03-72 (18 July 2005).

182. Prosecutor v. Milosevic, Second Amended Indictment "Kosovo," ICTY-02-54-T (16 October 2001).

183. Prosecutor v. Milosevic, Amended Indictment "Bosnia and Herzegovina," ICTY-02-54-T (22 November 2002).

184. Prosecutor v. Milosevic, Second Amended Indictment “Croatia," ICTY-02-54-T (28 July 2004).

185. Milosevic, Amended Indictment "Bosnia and Herzegovina," para. 32.

186. Milosevic, Second Amended Indictment "Croatia," paras. 37, 60, 61, 62, 66, 70, 72, 76, 83.

187. Ibid., para. 26(a).

188. Ibid., para. 36 .

189. Prosecutor v. Milosevic, Decision on Motion for Judgment or Acquittal, ICTY-02-54-T (16 June 2004), para. 116.

190. Ibid.

191. Bosnia Genocide, para. 219.

192. Milosevic, Decision on Motion for Judgment or Acquittal, para. 246.

193. Ibid., para. 257.

194. Ibid., para. 258.

195. Ibid., para. 249.

196. Ibid.

197. Groome, "Adjudicating Genocide," 975.

198. Ibid. 
199. Stakic, Judgment, para. 557. See also Brdanin, Judgment, paras. 910-62, 989.

200. Prosecutor v. Krstic, Appeals Judgment, ICTY-98-33-A (19 April 2004).

201. Prosecutor v. Krstic, Judgment, ICTY-98-33-T (2 August 2001), para. 579, citing Nikolia Jorgic, Bundesveerfassungsgericht [Federal Constitutional Court], Fourth Chamber, Second Senate, 12 December 2000, 2 BvR 1290/99, para. (III)(4)(a)(aa).

202. Ibid., para. 580 (emphasis added).

203. Krstic, Appeals Judgment, para. 33 (emphasis added).

204. Jorgic v. Germany (Application No. 74613/01), Judgment (12 July 2007).

205. Ibid., para. 104.

206. Ibid., para. 97; see also para. 41.

207. Ibid., para. 105; see also paras. 36, 47.

208. Bosnia Genocide, para. 190.

209. In Prosecutor v. Jelisic, the ICTY Trial Chamber held that genocide must involve the intent to destroy a "substantial" part of a group. As to the amount, the court observed "a targeted part of a group would be classed as substantial either because the intent sought to harm a large majority of the group in question or the most representative members of the targeted community." Prosecutor v. Jelisic, Judgment, ICTY-95-10-T (14 December 1999), para. 82.

210. Schabas, Genocide in International Law, 271.

211. Ibid., 271-72, citing "Report of the Commission to the General Assembly on the Work of its Forty-First Session," UN Doc. A/CN.4/Ser.A/1989/Add. 1 (Part 2), 102, para. (4).

212. Bosnia Genocide, 2007 I.C.J., para. 328.

213. Schabas, Genocide in International Law, 272 (emphasis added).

214. Prosecutor v. Blagojevic \& Jokic, Judgment, ICTY-02-60-T (17 January 2005), para. 675 (emphasis added).

215. Shaw, What Is Genocide? 157.

216. Rudolph L. Bindschedler, "Report," Judicial Settlement of International Disputes 144 (1974).

217. See SáCouto, Reflections on the Judgment of the International Court of Justice, 5.

218. See Keith Highet, "Evidence and Proof of Facts," in The International Court of Justice at a Crossroads, ed. Lori F. Damrosch, 355-75 (Ardsley, NY: Transnational Publishers, 1987), 372.

219. See Paul Schmitt, "The Future of Genocide Suits at the International Court of Justice: France's Role in Rwanda and Implications of the Bosnia v. Serbia Decision," Georgetown Journal of International Law 40 (2009): 585-623, 589, citing Michael R. Marrus and Robert O. Paxton, Vichy France and the Jews (New York: Basic Books, 1981); Randolph L. Braham, The Politics of Genocide: The Holocaust in Hungary, condensed ed. (Detroit: Wayne State University Press, 2000); and Joshua D. Zimmerman, Jews in Italy Under Fascist and Nazi Rule 1922-1945 (New York: Cambridge University Press, 2005).

220. Schmitt, "The Future of Genocide Suits," 589-90, 621-23. 